УДК 346.7

DOI https://doi.org/10.32849/2663-5313/2020.4.11

Тетяна Гудіма,

канд. юрид. наук, старший науковий співробітник

Інституту економіко-правових досліджень Національної академії наук Украйни

\title{
ЕКОНОМІКО-ПРАВОВІ ОСОБЛИВОСТІ РЕАЛІЗАЩІЇ ГРОШОВО-КРЕДИТНОЇ ПОЛІТИКИ В КРИЗОВИЙ ПЕРІОД (НА ПРИКЛАДІ ПАНДЕМІї COVID-19)
}

У статті досліджено економіко-правові особливості реалізації грошово-кредитної політики в кризовий період (на прикладі пандемії COVID-19) та запропоновано напрями щодо підвищення ї ефективності. Доведено, що, як носій монетарної влади, Національний банк України має реалізовувати відповідну політику у двох формах довгострокової (стратегічної) і поточної (тактичної), що спрямовані на оптимальне узгоження інтересів банків (як суб'єктів господарювання), споживачів банківських послуг та суспільства в иілому. Для підвищення ефективності виведення національноі економіки з кризи на системному рівні, зокрема своєчасності застосування засобів/методів грошово-кредитної політики, та зважаючи на глобальний масштаб і довготривалий характер кризової економічної ситуації, доцільною є розробка та затвердження Урядом «Стратегії виходу економіки країни із системної кризи, зумовленої епідемією вірусу COVID-19 на період з 2020 по 2022 роки» і щоквартальних планів заходів для кожного з органів державної влади, які реалізують різні напрями економічної політики.

Своєю чергою, попередження банкрутства стратегічно важливих підприємств, представників малого та середнього бізнесу та ін. $і$ водночас сприяння ефективному використанню бюджетних коштів, резервів Національного банку України актуалізує розробку та затвердження Урядом країни Порядку щодо фінансової підтримки підприємств (із визначенням процедури прийняття рішення щодо кредитування/підтримки того чи іншого підприємства) або окремих (стратегічно важливих) галузей економіки в період кризи, зумовленої пандемією COVID-19.

Аргументовано, що виведення економіки країни із системної кризи з боку иентрального банку має забезпечуватися впливом на діяльність суб'єктів господарювання, зокрема банківських та небанківських установ, иляхом застосування не лише тільки стимулюючих, але й обмежувальних економічних засобів, а також правових методів регулювання. Доводиться, що сприяння фінансовій стабільності, особливо у період кризи, набуває першочергового значення порівняно з метою забезпечення иінової стабільності.

Ключові слова: грошово-кредитна політика, COVID-19, економічна криза, фінансова підтримка підприємств, кредитування, Національний банк України, стратегія.

Постановка проблеми. Одним 3 основних факторів економічного розвитку будьякої держави є ефективна грошово-кредитна політика (далі - ГКП). В умовах трансформації економіки України, в тому числі спричиненої кризовими процесами, інструменти ГКП набувають вирішального значення. Проте успіх від їх застосування залежить від скоординованої дії всіх державних та недержавних фінансових інституцій, діяльність яких так чи інакше впливає як на внутрішні, так і зовнішні економічні процеси. Світові економічні кризи неодноразово підтверджували важливість розробки відповідної моделі такої взаємодії. Актуальність цього твердження доводиться і нещодавно розпочатими епідемічними процесами. Зокрема, поширення інформації про COVID-19 (1) стало своєрідним шоком не тільки для системи охорони здоров'я будь-якої країни, але й загалом для економічної системи, (2) зумовило необхідність взаємодії всіх державних інституцій, бізнесу, банківських установ та інших на шляху до мінімізації наслідків шоку, (3) поставило на порядок денний питання щодо зміщення акцентів у досягненні цілей грошово-кредитної політики та подальшої доцільності забезпечення принципу незалежності Центрального банку під час її реалізації.

Науковому аналізу органічного зв’язку ГКП 3 економічною політикою країни та всебічної ролі НБУ в подоланні макроекономічних криз присвятили свої роботи 
як вітчизняні, так і іноземні вчені та фахівці: С. Аржевітін, О. Бандура, В. Геєць, А. Гриценко, Т. Унковська, М. Савлук, О. Сугоняко, С. Кораблін, С. Моїсеєв, Jong-Wha Lee, Warwick J. McKibbin [1] та ін. Здобутки вчених становитимуть підгрунтя для виявлення особливостей реалізації ГКП в кризовий період, зокрема, зумовлений пандемією вірусу COVID-19, і наукових розробок у цьому напрямі.

Метою статті $є$ виявлення економікоправових особливостей реалізації ГКП в кризовий період (на прикладі пандемії COVID-19) та розробка пропозицій щодо напрямів підвищення її ефективності.

Виклад основного матеріалу. Пандемія вірусу COVID-19 негативно вплинула на загальні ланцюги та рівень поставок у світовій економіці, зокрема, через закриття заводів [2]. Але наскільки глибоким і стійким буде економічний ефект? Як це вплине на сукупний попит та яких слід вжити економіко-правових заходів щодо забезпечення стабілізації ГКП? Ці питання натепер перебувають у центрі запеклих дискусій не тільки наукової спільноти, а й фахівців-практиків. Їх вирішення вимагає врахування низки можливих сценаріїв.

Насправді, цілком можливим є те, що пандемія COVID-19 у результаті призведе до відносно м'якого і недовгострокового глобального економічного спаду, за яким слідуватиме V-подібне відновлення. Однак, з огляду на невизначеність, пов'язану з масштабами її поширення, доцільно брати до уваги i можливі макроекономічні наслідки більш песимістичних сценаріїв, зокрема: зниження попиту, збільшення розриву між попитом і пропозицією, посилення вразливості світової економіки до «застійних пасток» (епізодів низького зростання і високого безробіття) тощо. I в цьому разі для виведення останньої зі стагнації будуть потрібні активні заходи фіскальної та монетарної політик.

У будь-якому разі ті чи інші дії з боку уповноважених органів державної влади мають бути зумовлені наявністю надійної інформації, і не тільки про можливі зміни макроекономічних трендів, а й про поточний стан економіки (про іï «діагноз»). Інакше реакція регулятора на кризові процеси може стати не на часі (коли криза стає очевидною і досягає свого максимуму). За таких умов ефективність, зокрема, монетарних інструментів знижується, що призводить до збільшення часу, необхідного для відновлення економіки [3, с. 144]. Великого значення в цьому разі набуває прогнозування наслідків багатьох економічних явищ і процесів у грошово-кредитній сфері. Національний банк України (далі - НБУ) має реалізовувати відповідну політику у двох формах довгострокової (стратегічної) і поточної (тактичної), що спрямовані на оптимальне узгодження інтересів банків (як суб'єктів господарювання), споживачів банківських послуг та суспільства в цілому. Зважаючи на глобальний масштаб кризової економічної ситуації та той факт, що, за підрахунками вчених (зокрема, Інституту Роберта Коха (Німеччина)), пандемія COVID-19 може тривати два роки [4], видається доцільним розробка та врегулювання на законодавчому рівні «Стратегії виходу економіки країни з системної кризи, зумовленої епідемією вірусу COVID-19 на період з 2020 по 2022 роки» (робоча назва). Обов'язковою вимогою до їі виконання має бути обов'язкове щоквартальне затвердження плану заходів для кожного 3 органів державної влади, які реалізують різні напрями економічної політики. Такий підхід здатен унеможливити будь-які наслідки зміни політичного керівництва держави, тиску окремих органів, суб'єктів; дисциплінувати до виконання певних завдань тощо.

Для успішної протидії кризовій ситуації, розробки тактичних i стратегічних планів, вибору адекватних засобів впливу необхідним $є$ аналіз отриманих емпіричних відомостей та з'ясування екзогенних явищ, якими зумовлено порушення макроекономічної рівноваги, і того, на які з них має першочергово впливати регулятор. Чи вона зумовлена шоком пропозиції або попиту? На думку багатьох учених, у сучасній епідеміологічній ситуації (пандемія COVID-19), яка негативно вплинула на світову економіку, монетарна політика має реагувати на шоки попиту [5]. Відповідний підхід пояснюється тим, що падіння вартості загальних витрат, яке відбувається через збільшення попиту на гроші або зменшення кількості грошей, призводить до тимчасових макроекономічних збоїв. Сума загальних витрат не відповідає загальній вартості товарів, які передбачається продати за певний період. I в даному випадку падіння середнього рівня цін або збільшення кількості грошей можуть компенсувати цю невідповідність.

Інша річ - автономне падіння сукупної пропозиції. Негативний шок пропозиції сприяє падінню рівня виробництва, зокрема, у досліджуваному випадку, через тривале порушення ланцюгів поставок. Як наслідок, обсяг торгівлі падає i, ймовірно, буде продовжувати знижуватися, оскільки багато країн вживають обмежувальні заходи, пов'язані з карантином, для уповільнення поширення COVID-19. 
За інших рівних умов будь-яке падіння реального ВВП, яке ми відчуваємо, відповідатиме реальному діловому циклу, коли крива сукупної пропозиції зміститься вліво. Падіння доступності товарів призведе до загального зростання цін. У зв’язку з тим, що очікування швидко змінюються, ціни можуть випередити падіння пропозиції, адже люди поспішають у магазин, щоб запастися товарами. Збільшення кількості грошей в даному випадку тільки посилить цю проблему [5].

Своєю чергою, спроби компенсувати посилення інфляції через падіння доходів населення призведе тільки до подальших збитків держави, зокрема, через недоотримання податків та зборів, зниження ділової активності, в тому числі суб'єктів господарювання. Задля підтримки запланованого рівня інфляції в умовах негативного шоку сукупної пропозиції НБУ було б доцільно уповільнити темпи зростання запасів базових грошей в обігу. Це є фундаментальною проблемою між рівнем цін і таргетуванням інфляції. 3 метою сприяння запланованому рівню останньої негативний шок сукупної пропозиції має бути компенсований скороченням сукупного попиту.

Аналіз економічної ситуації та визначення екзогенних явищ, які сприяли виникненню кризи, змінюється наступним кроком - прийняттям рішення про застосування адекватних засобів впливу. Слушну думку висловлює І. Мілейко, який підкреслює важливість відокремлення правового складника. Мається на увазі законодавча політика держави - своєрідна «програма в програмі», яка передбачає план із прийняття, зміни або скасування нормативно-правових актів відповідно до встановлених пріоритетів та вибраних засобів (інструментів) [6].

Слід зазначити, що основним інструментом ГКП з боку регуляторів багатьох країн світу у відповідь на вищеописані процеси стало істотне зниження облікової ставки. Однією з перших країн, яка відреагувала таким чином на економічний вплив епідемії вірусу COVID-19, стали CША. На початку березня Федеральна резервна система прийняла рішення щодо зміни облікової ставки одразу на $0,5 \%$. Такого значного зниження не відбувалося більш ніж 10 років, після фінансової кризи 2008 року. Дії ФРС стали прикладом для інших розвинених країн і країн, що розвиваються [7].

Подібна практика не оминула Україну. Зокрема, у відповідь на епідеміологічні виклики правлінням НБУ було ухвалено рішення щодо зниження облікової ставки до $10 \%$ річних з 13 березня 2020 року [8]. Втім, для ряду центральних банків Свропи та Японії реалізація вищеописаного засобу обмежується вже наявними негативними ставками [7].

Повертаючись до прикладу США, слід звернути увагу, що відповідні дії ФРС не справили на інвесторів позитивного впливу. Акції підприємств продовжили «падіння» на ринку. Індекс S\&P500, наприклад, знизився більш ніж на $3 \%$, а дохідність по десятирічним американським державним облігаціям знизилася більш ніж на 1\%. 3 позиції фахівців, «ФРС мала б зробити більше, ніж просте, хоча і досить сильне (за теперішніх часів) зниження облікової ставки». Втручання центральних банків для пожвавлення світової економіки таким чином не здатне принести очікуваних результатів. На думку Джона Хопкінса, згідно із законодавством регулятор має незначний набір засобів, ті, що $\epsilon$ в його розпорядженні, зовсім не підходять для реагування на потенційний значний шок пропозиції [7]. Грошові кошти здатні оживити економіку в тому разі, якщо причиною рецесії $€$ неефективна фіскальна політика держави або зміна курсу валют з будь-яких політичних та економічних причин.

Незважаючи на це, в багатьох країнахучасницях $\in C$, зокрема Великобританії, поряд зі зниженням облікової ставки, було впроваджено заходи щодо цільового рефінансування банків з метою подальшого кредитування малих та середніх підприємств. Так, трьома комітетами Банку Англії було прийнято рішення про вжиття заходів щодо надання допомоги бізнесу та домогосподарствам Великобританії в подоланні економічного кризи, пов'язаної з епідемією COVID-19 [9]. Зокрема, діяльність підприємств в умовах рецесії або загалом призупинення їхньої діяльності (як, наприклад, в Україні відповідно до постанови Кабінету Міністрів України від 11 березня 2020 р. № 211 «Про запобігання поширенню на території України коронавірусу COVID-19» заборонили діяльність окремих підприємств до 3 квітня 2020 р.) на декілька тижнів/місяців здатне позбавити їх прибутку, що значно ускладнює вирішення питання сплати орендної плати, податків та інших обов'язкових платежів, заробітної плати працівникам. Своєю чергою, співробітники відповідних установ мають сплачувати іпотечні платежі, оренду, платежі за споживчими кредитами тощо За таких умов $є$ вірогідність виникнення ризику масових банкрутств як з боку підприємств, так і з боку домогосподарств (що зумовлено звільненням, затримкою заробітної плати, відправленням у відпустку без збереження заробітної плати з причини відсутності доходів підприємств). Як наслідок, 
це може справити негативний вплив на стабільність фінансових установ.

Поряд із цим є вірогідність настання протилежної ситуації. Негативний шок сукупної пропозиції може призвести до негативного шоку сукупного попиту (у разі, якщо падіння ділової активності погіршить платоспроможність позичальників). У результаті суб'єкти (фізичні та юридичні особи) виявляться неспроможними здійснювати платежі в рахунок погашення кредитів або відкривати поновлювані кредитні лінії, від яких зазвичай залежить іхній бізнес. Або попит на кредит за наявними ставками може впасти з причини уповільнення торгівлі. Важливим аспектом, на який доцільно звернути увагу в даному випадку, є визначення характеру (тимчасового або пролонгованого) деструктивних процесів в економіці. У разі тимчасового збою в ланцюгах поставок або легкого шоку з боку попиту, що призводить до затримки споживання, банки зможуть підтримувати підприємства - постійних клієнтів банку [10; 11], грунтуючись на знаннях щодо діяльності і фінансового стану підприємства, а також довгострокових планів останнього.

Більш тривале економічне уповільнення або навіть спад здатні сприяти тиску на кредитні портфелі банків і позиції платоспроможності. Водночас є ризик того, що «непрацюючі» кредити (а також нормативно встановлені заходи щодо «заморожування» виплат та штрафних санкцій за кредитом) виявляться прямим джерелом фінансової нестабільності банків. Гіпотетично виникнення подібної ситуації («непрацюючих» кредитів) прогнозується не в найближчому періоді, а, швидше (за негативного або несприятливого сценарію), у другій половині 2020 року [12]. Звичайно, мінімізувати негативні наслідки можна було б за наявності можливостей повернення втраченого ВВП та надання кредитів під гарантію майбутніх доходів. Але навряд чи це $є$ економічно можливим. Зважаючи на це, НБУ має вжити заходів щодо посилення контролю на кредитному ринку та здійснювати на постійній основі оцінку фінансового стану банківських та небанківських установ, які надають кредитні послуги.

Однією з відправних точок для реалізації цього завдання є стрес-тести (на зразок тих, що проводяться регуляторами на міжнародному рівні [13]) із подальшим інформуванням суспільства про результати його проведення і вжиття відповідних заходів. Прозорість дій регуляторних органів для громадян є досить важливим аспектом, про що свідчить минулий досвід подолання кри- зових явищ [14]. Натомість в Україні [15], а також деяких зарубіжних країнах (зокрема, Великобританії [16]) в сучасних умовах було прийнято рішення про відтермінування проведення стрес-тестування, впровадження буферів капіталу та скасування виїзних перевірок банків з боку регулятора. Слід зазначити, що на вітчизняному рівні згідно з Методичними рекомендаціями щодо порядку проведення стрес-тестування в банках України, затвердженими Постановою Правління НБУ від 06.08.2009 р. № 460, застосування цього інструменту, навіть в нормальних умовах функціонування економіки, має рекомендаційний характер (п. 1.4).

Втім, на думку вчених та практиків, проведення стрес-тестів та посилення контролю з боку регуляторних органів, особливо в кризовий період, є вкрай необхідним та обгрунтованим [17; 18]. Таким чином банки мають закладати основу для виявлення довгострокових стратегічних наслідків і забезпечувати плавний перехід від сьогодення до майбутнього. Очевидним є те, що особливості проведення стрес-тестів в тій чи іншій країні можуть бути відмінними залежно від економічної ситуації (як у цілому, так і в окремому регіоні).

Загалом, аналіз заходів центральних банків різних країн дозволяє дійти висновку про те, що в кризовий період методи та засоби ГКП переважно спрямовуються на забезпечення фінансової стабільності, факультативно сприяючи досягненню цінової стабільності. Зокрема, запобігання можливим дисбалансам фінансової системи (в тому числі зумовленим неплатоспроможністю позичальників), а також зміцнення довіри до фінансових ринків (інформування населення щодо можливих ризиків та готовності втручання) виходить на перший план.

Слід також врахувати ту обставину, що резервів НБУ може не вистачити для довготривалого фінансування підприємств. Це, своєю чергою, актуалізує питання щодо здійснення додаткової емісії національної валюти. Однак збільшення пропозиції в такому разі здатне негативно вплинути на інфляційні очікування. Задля протидії виникненню подібних ситуацій (у тому числі необгрунтованій емісії) видається за доцільне посилити з боку НБУ контроль за цільовим використанням кредитних коштів банками i, відповідно, підприємствами. Поряд із цим з метою забезпечення економіки країни коштами (там де це є вкрай необхідним), виключення можливості махінацій у цій сфері необхідно розробити (спільно з НБУ) та затвердити Уряду країни стратегічний план/порядок фінансової підтримки 
підприємств (iз визначенням процедури прийняття рішення щодо кредитування того чи іншого підприємства) або окремих (стратегічно важливих) галузей економіки.

\section{Висновки}

Проведений аналіз дозволяє дійти таких висновків:

1. Як носій монетарної влади, НБУ має реалізовувати відповідну політику у двох формах довгострокової (стратегічної) і поточної (тактичної), що спрямовані на оптимальне узгодження інтересів банків (як суб'єктів господарювання), споживачів банківських послуг та суспільства в цілому. Для підвищення ефективності виведення національної економіки 3 кризи на системному рівні, зокрема своєчасності застосування засобів/методів грошово-кредитної політики, та зважаючи на глобальний масштаб і довготривалий характер кризової економічної ситуації, видається доцільним розробка та затвердження Урядом «Стратегії виходу економіки країни з системної кризи, зумовленої епідемією вірусу COVID-19 на період з 2020 по 2022 роки» (робоча назва) з обов'язковим затвердженням плану заходів (щоквартально) кожного з органів державної влади, які реалізують різні напрями економічної політики.

2. 3 метою протидії банкрутству стратегічно важливих підприємств, представників малого та середнього бізнесу та ін. і водночас ефективного використання бюджетних коштів, резервів НБУ доцільно розробити та затвердити Уряду країни Порядку щодо фінансової підтримки підприємств (із визначенням процедури прийняття рішення щодо кредитування/підтримки того чи іншого підприємства) або окремих (стратегічно важливих) галузей економіки в період кризи, зумовленої пандемією COVID-19.

3. Виведення економіки країни із системної кризи, зумовленої пандемією вірусу COVID-19, з боку центрального банку має забезпечуватися впливом на діяльність суб'єктів господарювання, зокрема банківських та небанківських установ, шляхом застосування не лише стимулюючих, а й обмежувальних економічних засобів і правових методів регулювання. До стимулюючих засобів можна віднести: зниження облікової ставки, вимог під формування резервів, рефінансування; серед обмежувальних засобів слід виділити: обмеження коштів рефінансування цільовим призначенням, валютні обмеження тощо.

4. 3 метою попередження вірогідності банкрутства банківських установ, центральному банку було б доцільно контролювати ситуацію на кредитному ринку та на постійній основі здійснювати оцінку фінансового стану банківських та небанківських установ, які надають кредитні послуги. Однією з відправних точок для реалізації цього завдання слід виділити стрес-тестування. Обгрунтовано, що в умовах економічної кризи проведення стрес-тестів має здійснюватися в обов'язковому порядку та 3 одночасним інформуванням Центрального банку. Задля забезпечення вимоги обов'язковості, а також визначення періодичності та умов їх здійснення в кризовий період відповідні положення доцільно закріпити на законодавчому рівні.

5. Аргументовано доцільність зміщення акцентів у першочерговості цілей грошовокредитної політики в кризовий період. Доведено, що в кризовий період Національний банк України, всупереч законодавчо закріпленій вимозі щодо пріоритетності досягнення та підтримки ним цінової стабільності в державі (стаття 99 Конституції України, стаття 6 ЗУ «Про НБУ»), у межах своїх повноважень насамперед має сприяти фінансовій стабільності, в тому числі стабільності банківської системи. Зважаючи на це, запропоновано внести зміни до Конституції України та статті 6 Закону України «Про НБУ , закріпивши положення такого змісту: «основними функціями Національного банку є сприяння фінансовій стабільності та забезпечення стабільності грошової одиниці України. У виконанні своїх основних функції Національний банк має виходити із пріоритетності досягнення тієї з них, яка $\epsilon$ важливою в певний проміжок часу та/або на перспективу. Економічне обгрунтування пріоритетності функцій має публікуватися в щомісячних звітах про діяльність Національного банку».

\section{Список використаних джерел:}

1. Jong-Wha Lee, Warwick J. McKibbin. Globalization and Disease: The Case of SARS». Departmental Working Papers 2003-16, The Australian National University, Arndt-Corden Department of Economics. URL: https://www.brookings.edu/ research/globalization-and-disease-the-case-ofsars-2/ (дата звернення: 22.03.2020).

2. OECD Interim Economic Assessment Coronavirus: The world economy at risk 2 March 2020 URL: http://www.oecd.org/berlin/publikationen/Interim-Economic-Assessment-2-March-2020.pdf (дата звернення: 22.03.2020)

3. Бандура О.В Системні економічні кризи та роль макрорегуляторів в іх подоланні. Політика Начіонального Банку Украӥни щодо подолання фінансово-економічної кризи і формування монетарних передумов розвитку економіки : матеріали науково-практичної конференції, 5-6 листопада 2015 р. Київ : КНЕУ. С. 143-163. 
4. Пандемія коронавірусу може тривати 2 роки - німецький інститут. URL: https:// www.pravda.com.ua/news/2020/03/17/7243945/ (дата звернення: 22.03.2020).

5. James L. The Coronavirus Reveals the Limits of Monetary Policy. URL: https://www.aier.org/ article/the-coronavirus-reveals-the-limits-of-monetary-policy/ (дата звернення: 24.03.2020).

6. Милейко И. Структурно-отраслевая политика государства: правовые аспекты реализации. Підприємниитво, господарство та право. 2005. № 3. C. 21-24.

7. ФРС США пошла на экстренные меры из-за коронавируса. URL: https://expert.ru/2020/ 03/4/frs/ (дата звернення: 29.03.2020).

8. Рішення Правління Національного банку України від 12 березня 2020 року № 172-рш «Про розмір облікової ставки». URL: http:// search.ligazakon.ua/1_doc2.nsf/link1/PB20041. html (дата звернення: $\overline{2} 9.03 .2020$ ).

9. Bank of England measures to respond to the economic shock from COVID-19. URL: https:// www.bankofengland.co.uk/news/2020/march/boemeasures-to-respond-to-the-economic-shock-fromcovid-19 (дата звернення: 23.03.2020).

10. Beck T., Degryse H. and N Van Horen. When arm's length is too far: Relationship banking over the credit cycle, Journal of Financial Economics. 2018. 127(1). P. 174-196.

11. Bolton P., Freixas X., Gambacorta L. Mistrulli P. Relationship and Transaction Lending in a Crisis. Review of Financial Studies. 2016. 29(10). P. 2643-2676.

12. Thorsten Beck. Finance in the times of coronavirus Cass Business School and CEPR. Economics in the Time of COVID-19. A CEPR Press VoxEU. org eBook. 2020. P. 73-77.

13. Andreas A. Jobst, Li Lian Ong and Christian Schmieder A Framework for Macroprudential Bank Solvency Stress Testing: Application to S-25 and Other G20 Country FSAPs. IMF Working Paper Monetary and Capital Markets Department. 2013. P. $1-48$.

14. John M. Barry. The great influenza. The epic story of the deadliest plague in history. 2004.Viking Books: New York, New York, USA. 546 p.

15. Joint letter to the UK banks. URL: https://www.bankofengland.co.uk/-/media/boe/ files/letter/2020/covid-19-and-bank-lending. pdf?la=en\&hash=2C9C1BDD88BBD0746F4049B985279913ВА6В2344 (дата звернення: 26.03.2020).

16. Національний банк обговорив 3 топменеджерами найбільших українських банків роботу фінсектору в умовах карантину. URL: https://bank.gov.ua/news/all/ natsionalniy-bank-obgovoriv-z-top-menedjerami-naybilshih-ukrayinskih-bankiv-robotu-finsektoru-v-umovah-karantinu (дата звернення: 29.03.2020)

17. Coronavirus Crisis Shows That Banks Need To Conduct More Strenuous Stress Tests Now. URL: https://www.forbes.com/sites/mayrarodriguezvalladares/2020/03/18/coronacrisis-crisis-shows-thatbanks-need-to-conduct-more-strenuous-stress-testsnow/\#50d5dbf92521 (дата звернення: 29.03.2020).

18. Big banks want regulation eased because of coronavirus. Experts call it opportunistic. URL: https://www.washingtonpost.com/business/ 2020/03/03/banks-lobby-coronavirus/ (дата звернення: 29.03.2020).

The article examines the economic and legal features of the implementation of monetary policy in a crisis period (on the example of the COVID-19 pandemic) and suggests directions for improving its effectiveness. It is proved that as a bearer of monetary power the National Bank of Ukraine should implement the relevant policy in two forms of long-term (strategic) and current (tactical), aimed at optimal alignment of interests of banks (as economic entities), consumers of banking services and society as a whole. In order to increase the efficiency of the national economy's recovery from the crisis at the systemic level, including timely application of monetary policy tools / methods, and given the global scale and long-term nature of the crisis economic situation, it is advisable to develop and approve the Government's Strategy for Exiting of the Systemic Economy crisis caused by the COVID-19 virus epidemic for the period from 2020 to 2022 »with the mandatory approval of the plan of action (quarterly) of each of the public authorities implementing different directions of economic policy.

In turn, in order to counteract the bankruptcy of strategically important enterprises, representatives of small and medium-sized businesses, etc. and at the same time effective use of budgetary resources, reserves of the National Bank of Ukraine, it is advisable to develop and approve by the Government of the Country Procedure for financial support to enterprises (defining the procedure for deciding on lending / support of a particular enterprise) or specific (strategically important) sectors of the economy in times of crisis, caused by the COVID-19 pandemic.

It is argued that in order to bring the country's economy out of the systemic crisis, the Central Bank should influence the activities of economic entities, in particular banking and non-banking institutions, by applying not only incentive but also restrictive economic means, as well as legal methods of regulation. It is argued that the objective of promoting financial stability, especially in times of crisis, is of paramount importance compared to the objective of ensuring price stability.

Key words: monetary policy, COVID-19, economic crisis, financial support to enterprises, lending, National Bank of Ukraine, strategy. 